\title{
BRICS Regional Policy in Africa
}

\author{
T. Deych
}

Tatiana Deych - PhD, Leading Research Fellow, Institute for African Studies Russian Academy of Sciences; 30/1 Spiridonovka St., 123001 Moscow, Russian Federation; E-mail: tdeich@yandex.ru

This article analyzes the policies of the BRICS grouping of Brazil, Russia, India, China and South Africa as a whole and individually in Africa. It also explores their political and economic interests in Africa and the various patterns and strategies of each country's cooperation with Africa, and estimates the impact of BRICS aid and investment on the African economy and development. The BRICS members have emerged as the new effective actors in the world arena. Their economic weight and political influence are growing. They are focused not only on strengthening their ties within the association, but also on assistance to Africa as a way for emerging powers to change the existing world order. The BRICS is deepening its engagement with African countries, which have had great successes in development in recent years. BRICS members' attention to Africa is determined by its resource potential and its growing influence in the world economy and contemporary international relations. BRICS countries are large trading partners of Africa, and Africa's trade with BRICS members is growing faster than with its traditional partners. Africa has become the main destination for BRICS development aid and investment. BRICS members focus particularly on African infrastructure. They use soft power widely in developing humanitarian ties with Africa, particularly in health care and education. The BRICS is also an active participant in peacekeeping and conflict resolution in Africa. The five countries increasingly collaborate in Africa rather compete. The BRICS thus contributes much to African economics, and its presence on the continent has become an important and welcome phenomenon.

Key words: BRICS, Africa, China, Russia, India, Brazil, South Africa, resources, economic growth, development, cooperation, policy, trade, aid, investment, infrastructure, soft power, security, peacekeeping, competition, partnership.

\section{Why Africa? What's in It for the BRICS?}

In the last decade, Africa has become a focus for the BRICS group of Brazil, Russia, India, China and South Africa, becoming the base for implementing its efforts to change the existing world order. Africa is a treasure of natural resources, which particularly interest China, India and Brazil. At the same time, it is a conglomeration of underdeveloped countries in need of assistance. By cooperating with these countries, the BRICS demonstrates its ability and willingness to do things that Africa's earlier partners could not do. By positioning themselves as the defenders of the interests of developing countries, the five BRICS emerging economies pursue a complex aim: first to satisfy their own need for natural resources and commodity markets, then to promote the sustainable development of African countries. At the same time, they work to improve their image and show what South-South truly cooperation means.

Among recent reasons for the expanding BRICS involvement in Africa is the growing influence of African countries in the global economy and contemporary international relations. The BRICS interest in Africa is dictated, to a large extent, by the economic success of African countries. If, in the 1990s, the growth of Africa's gross domestic product (GDP) remained at $2.3 \%$, in the 21 st century it has already averaged $5 \%$. Six African countries were among the 10 
fastest growing economies in the world between 2001 and 2010 [Ernst and Young, 2011]. According to the International Monetary Fund (IMF), of the 22 countries that will expand by at least $7 \%$ a year on average between 2014 and 2019 - a rate that enables an economy to double its size in a decade - 14 countries will be in Africa [Marlier, 2014].

Six BRICS summits have now taken place. The theme of the fifth BRICS summit in Durban, South Africa, in March 2013 was "BRICS and Africa: Partnership for Development, Integration and Industrialization" [BRICS, 2013]. Africa was well represented at that summit. South African president Jacob Zuma invited 15 African leaders and eight representatives of regional organizations, including Nkosazana Dlamini-Zuma, chair of the African Union (AU) Commission. The summit resulted in the adoption of solutions that were important for Africa, particularly the agreement on co-financing BRICS infrastructure projects [Shubin, 2013]. The Ethekwini Declaration, issued at Durban, showed that African problems are among the priorities of BRICS policy [BRICS, 2013]. At the sixth BRICS summit in 2014 in Fortaleza, Brazil, the leaders discussed strengthening cooperation with African countries, primarily in the areas of infrastructure and industrialization [BRICS, 2014].

The BRICS action plans, included in the summit declarations, provides aid to Africa in the form of implementing strategies for sustainable development, including food and energy security, new technologies and innovation policy, in addition assisting in building infrastructure, pursuing a joint search for models of political systems and modernizing social structures. They also include issues important for Africa such as the environment, climate change, and crisis and conflict response.

\section{The Growing Trade between the BRICS and Africa}

The idea that the BRICS countries are redrawing the economic landscape of the African continent came through in a report published by South Africa's Standard Bank in 2011 [World Bank, 2011]. They have strengthened their presence in Africa compared with Africa's traditional partners, such as the United States and the European Union, and their mutual trade is growing. Total BRICS trade with Africa rose from $\$ 22$ billion in 2000 to $\$ 340$ billion in 2012 and is projected to reach $\$ 500$ billion by 2015 [United Nations Economic Commission for Africa (UNECA), 2013]. Africa's trade with the BRICS grew faster than its trade with any other region in the world. Currently, BRICS members trade more with Africa than they do among themselves [African Development Bank (AfDB), 2013]. India's and China's trade with Africa as a proportion of GDP in 2012 was $1.4 \%$ and 1.6\%, respectively; for Brazil it was $1.2 \%$, Russia 0.3\% and South Africa 4\% (in 2011) [Sandrey, Fundira, Vink et al., 2013, p. 19].

China has surpassed the United States to become Africa's largest trading partner. SinoAfrican trade increased from \$11 billion in 2000 to \$210.2 billion in 2013 [China Analyst, 2014]. "Today, China accounts for $20 \%$ of Africa's trade ... Africa is China's fastest-growing export destination and trade partner," according to Standard Bank [2012]. South Africa's bilateral trade with China in 2013 increased by 32\% over the previous year, according to official data. Two-way trade between these two countries increased from $\$ 19.2$ billion in 2012 to about $\$ 25$ billion at the end of 2013 [TBP and Agencies, 2014].

India-Africa overall trade grew from 2005 to 2011 by 32.4\%, which is higher than ChinaAfrica trade growth at 27\% [Confederation of Indian Industry (CII) and World Trade Organization (WTO), 2013, p. 18]. India-Africa trade amounted to $\$ 46$ billion in 2010, and rose to $\$ 70.3$ billion in 2012. At the third Africa-India Trade Ministers Dialogue in 2013, the target for bilateral trade for 2015 was revised to $\$ 90$ billion from $\$ 70$ billion, which had been set at the first meeting. The top six African exporters of Nigeria, South Africa, Angola, Egypt, Algeria 
and Morocco account for $89 \%$ of total African exports by value to India, thanks mainly to the export of oil, ore and gold. In 2011 the top six had a trade surplus above $\$ 24.5$ billion, and by the end of 2015 their trade surplus could reach $\$ 67$ billion. However, 40 of the 54 African countries have a negative balance in trade with India [CII and WTO, 2013, pp. 16-17]. As an importer of oil and other natural resources, India has diversified its trading partners beyond its traditional East African partners to include oil-rich Nigeria and resource-rich South Africa. Uranium from Niger, Uganda and Tanzania is also vital to India's nuclear power industry.

In the past decade, Africa has become one of Brazil's fastest growing trade partners. Brazilian_trade to the continent expanded from $\$ 4.3$ billion in 2000 to $\$ 28.5$ billion in 2013 [Muggah, 2015]. North Africa, South Africa and Nigeria account for two thirds of Brazilian exports to Africa. Nigeria accounts for over half of Brazil's African imports, all of which is crude oil. Lusophone Africa accounts for just $12.6 \%$ of exports and $5.5 \%$ of imports (mostly Angola). Brazil's trade deficit with Africa has averaged \$2.5 billion per year [George, 2014].

Africa is the main supplier of natural resources for the BRICS countries. Mineral fuels account for $70 \%$ of Africa's exports to China, $80 \%$ of exports to India and $85 \%$ of exports to Brazil. China, India and Brazil account for one quarter of all African exports (slightly more than $10 \%$ in 2005). China is the second export market for Africa after the EU, India is in fourth place, Brazil in sixth. These three countries account for almost 22\% of African imports (13\% in 2005). African imports from India grows annually by $23.1 \%$, from China - by $25.6 \%$, from Brazil - by $12 \%$ [CII and WTO, 2013, p. 19].

Russia lags behind other BRICS countries in trade and economic cooperation with Africa. According to the statistics produced by the Russian Federation, its trade turnover with Africa amounted to $\$ 9.6$ billion in 2012, while Standard Bank calculated it at $\$ 9.4$ billion [Korendyasov, 2014, p. 241; Freemantle and Stevens, 2013]. African exports to Russia account for only $1 \%$ of the continent's exports to the BRICS countries. Russian exports to Africa have recently increased slightly and account $7 \%$ of BRICS countries' exports to the continent. Russia's main import partners are South Africa (22\%), Morocco (19\%) and Egypt (13\%); its main export partners are Egypt (48\%), Morocco (16\%) and Tunisia (12\%) [Green, 2012]. Russia introduced a preferential trade system for African exporters of traditional export goods to remove import duties and restrictions. After South Africa became a member of the BRICS, its trade with other African countries rose from $\$ 21.4$ billion in 2011 (South African exports were \$13.81 billion and its imports were $\$ 6.55$ billion) to $\$ 24.5$ billion in 2012 (export were $\$ 14.49$ billion, imports were $\$ 10.02$ billion) [Sandrey, Mpitsa, Vermaak et al., 2013]. The creation of the BRICS-Africa Export-Import Forum in 2012 further promoted bilateral trade.

\section{The BRICS as a Donor in Africa}

The BRICS contribution to development financing has increased over the last years. The BRICS has become an important actor in development aid to African countries. China is leader in this area of cooperation. It provides assistance to almost all African states, although the main beneficiaries are the resource-rich countries. The fifth ministerial conference of the Forum on China-Africa Cooperation (FOCAC) in Beijing in 2012 adopted the Beijing Action Plan (2013-2015). It laid out steps that include measures to support regional integration and sustainable development and emphasized the need for cooperation in agriculture and food security. China has pledged to provide African countries loans worth $\$ 20$ billion - twice as much as that pledged at the 2009 FOCAC meeting [Hu, 2012]. During a visit to Africa in May 2014, Premier Li Keqiang announced the new loans to African countries in the amount of $\$ 10$ billion [Blanchard, 2014]. On 24 October 2014, President Xi Jinping announced an assistance package 
of $\$ 81.7$ million to fight Ebola, as China continues its commitment to preventing the spread of the deadly virus in West Africa [Shan, 2014]. China also cancelled \$30 billion in the debts of 35 African countries.

According to the white paper "China-Africa Trade and Economic Co-operation," between 2010 and 2012 China approved concessional and soft loans to 92 African projects in the amount of at least $\$ 11.3$ billion ( $\$ 4.7$ billion per year). Most were granted by the Export-Import Bank of China (China Eximbank) [People's Republic of China, 2013]. Between 2000 and 2011, China carried out 1,673 non-investment projects in infrastructure, transport and energy worth $\$ 75.4$ billion in 50 African countries [UN Integrated Regional Information Networks, 2013].

India has also increased its development aid to African countries. Africa accounts for more than $60 \%$ of the credits offered by the Export-Import Bank of India (India Exim Bank). From April 2009 to June 2014, India provided Africa $\$ 4.2$ billion in loans, with $36 \%$ in agriculture and $23 \%$ in energy [Jacob, 2015]. The main beneficiaries between 2005 and 2013 Ethiopia (\$1,004.5 million), Sudan (\$691.9 million) and Mozambique (\$639.4 million) [Mullen, 2014, p. 4]. One completed project is a power plant with the capacity of 120 megawatts (MW) in Zambia, built by Tata Steel. Indian technologies have allowed Uganda to triple its energy supply from $300 \mathrm{MW}$ to 1,000 MW. At the the third Africa-India trade ministers meeting in Johannesburg in October 2013, South Africa's Rob Davis said that: "India is ideally placed to help Africa industrialise ... Africa was now at a point where it needed to industrialise ... to move beyond the extraction and export of commodities to the production of value-added goods" [SA News, 2013].

Under Lula, Africa was among the first recipients of Brazilian aid and remains a significant recipient today. Brazil has cancelled $\$ 900$ billion in African debts. The Brazilian Agency of Cooperation (Agência Brasileira de Cooperação, $\mathrm{ABC}$ ) has developed 77 technical cooperation projects, more than half in Africa, with particular attention to the agricultural sector. In 2012, Brazil set up a national programme for farm development that increased family-based agriculture. Brazil takes its experience to the African countries. The success of its agricultural model is due mainly to the vertical integration of the sector, strong support from the state and a high level of mechanization. The Brazilian Agricultural Research Corporation (EMBRAPA), which has 47 research centres and 14 technology transfer centers, provides financial and credit support to farmers. After opening an office in Accra, Ghana, in 2006, it engage in projects in more than 13 African countries. It now has offices in Mali, Mozambique and Senegal; it is helping to develop production of soybeans, sugar cane, corn and cotton in Tanzania; and it has established an agency of agricultural technologies in Ethiopia. EMBRAPA is implementing a cotton-growing project (Cotton-4) in Mali that has been extended to Benin, Burkina Faso and Chad. The goal is to increase the production of cotton in four African countries [Borzova, 2014, p. 285]. It will also be extended to Togo. Students from the Democratic Republic of Congo (DRC), Nigeria and Tanzania are exploring EMBRAPA's innovative technologies [Juma, 2013]. A recent field of Brazil activity in Africa has been the production of biofuels in Mozambique, Angola and Nigeria.

Russia renders assistance to Africa mainly through international organizations and foundations. Russia has cancelled \$20 billion in African debts. From 2009 to 2012 it provided $\$ 100$ million to least developed countries (LDCs) [RT, 2012]. Since 2005 Russia has been making regular payments to the World Food Programme. Assistance was provided to ensure food security (\$244 million) and health care. It has contributed \$235 million to the Global Fund to Fight AIDS, Malaria and Tuberculosis as well as $\$ 30$ million to fund the fight against the Ebola epidemic in West Africa. From 2009 to 2012, Russia has paid \$32 million to support education programmes, mainly in African countries. In 2013 it provided 750 scholarships for Africans to study in Russian universities [Vasilyev and Korendyasov, 2014]. 
Since independence South Africa has positioned itself as a partner of African countries within the framework of South-South cooperation. As president, Thabo Mbeki was one of the initiators of the New Partnership for Africa's Development (NEPAD). According to Sven Grimm [2013, p. 39], director of the Centre for Chinese Studies at Stellenbosch University, South Africa is a "medium-size" donor. Its advantageous financing facilities include regional organizations, primarily the AU and the Southern Africa Development Community (SADC). South Africa also provides humanitarian assistance to LDCs, including South Sudan, Congo and Rwanda.

In recent years, the African Renaissance and International Cooperation Fund has provided funding of \$45-\$75 million annually in approximately 20 projects, in particular to support states emerging from conflict situations and to assist the holding of elections (such as in the DRC and Sudan) [Tjønneland, 2013].

\section{BRICS-Africa Investment Cooperation}

The BRICS has become a significant investor in Africa. The BRICS countries have strengthened their presence on the continent compared to traditional partners such as the United States and the European Union. In 2010, for example, the BRICS share in inward stocks of foreign direct investment (FDI) reached 14\% and FDI inflows to Africa reached 25\%. Among the top 20 investors in Africa in 2011, China, India, South Africa were ranked fourth, fifth and 17th in terms of FDI flows; South Africa, China, India and Russia were the fifth, sixth, seventh and 15th largest holders of FDI stock. The BRICS share in the total value of African greenfield projects reached 25\% in 2012 compared to $19 \%$ in 2003 [UN Conference on Trade and Development (UNCTAD), 2013a, b]. The total investment of BRICS members in Africa represented a quarter of the continent's total inflows for 2012. FDI stock to other BRICS countries accounted for only $3.2 \%$ of Indian outward stock, $2.2 \%$ of Chinese outward stock, and $0.3 \%$ of Russian and Brazilian outward stock. Chinese investments in South Africa, meanwhile, continued to grow. Between January 2003 and January 2014, there were 38 FDI Chinese projects in South Africa. These projects represent a total capital investment of about $\$ 1.24$ billion, which is an average $\$ 33$ million invested per project [TBP and Agencies, 2014].

For some experts, the BRICS engagement in Africa is driven only by the continent's abundant natural resources. The BRICS countries are significant exploiters of natural resources in many African countries. However, natural resources do not represent the main BRICS investment in Africa. According to UNCTAD [2013a], 75\% of the value of BRICS FDI in Africa between 2003 and 2012 was in manufacturing and services. Only 10\% of projects and 26\% of their value were in the natural resources and agricultural sectors [AfDB, 2013]. BRICS FDI in African projects in the manufacturing and services sectors has positive consequences for job creation and industrial growth.

The biggest investor among the BRICS countries is China. According to its FDI Statistic Bulletin for the year to September 2013, China increased its outbound FDI to a record $\$ 87.8$ billion, up $17 \%$ percent since 2012, in sharp contrast to global foreign investments, which declined by the same amount [Patlansky, 2014]. Chinese outbound direct investment in Africa totalled $\$ 25$ billion by the end of 2013. Speaking at Africa Investment Summit in Hong Kong in November 2013, Zhao Changhui, China Eximbank's chief country risk analyst, said that China had pledged to provide $\$ 1$ trillion in financing to Africa up to 2025 to be invested in infrastructure, industry and agriculture [Kuo, 2013].

Some sources estimate the stock of Indian investment in Africa at over \$32 billion [CII and WTO, 2013, p. 18]. At the CII-Exim Bank Conclave on the India-Africa Project Partnership in New Delhi in March 2013, 622 Indian and 893 African representatives from 45 African 
countries discussed 477 projects worth $\$ 68.37$ billion. The nine conclaves from 2005 to 2013 attracted 7,641 delegates, including 3,791 from Africa, with 1,985 projects worth $\$ 172$ billion discussed [CII and WTO, 2013, p. 52]. The India-Africa Project Partnership promotes the development of small and medium-sized enterprise in Africa.

Brazil's investments in Africa are concentrated in the mining, construction, agriculture, biodiesel, energy and pharmaceutical industries. They go mainly to Lusophone Africa (Angola and Mozambique) and to oil suppliers (Algeria and Nigeria). Brazil has expanded its business in the ethanol industry in Angola, Ghana and Mozambique [UNCTAD, 2013a].

The direct investments of Russian companies in Africa were estimated for 2012 to be approximately $\$ 9$ billion. The volume declared for 2013 to 2020 was $\$ 17$ billion. Russian investment in Africa accounted for 2013 to approximately 4\% of its FDI stock (\$362 billion) and approximately 3\% of all FDI stock in Africa (\$560-570 billion) [Korendyasov, 2013, p. 100]. Up to $80 \%$ of Russian investment was directed to the exploration and extraction of natural resources.

South Africa is becoming a visible investor in African countries, particularly in the form of public-private partnerships, which involve contracts between public and private sectors. Its projects cover several countries including Burundi, Djibouti, the DRC, Egypt, Ethiopia, Kenya, Rwanda, Sudan, Tanzania and Uganda. In 2012 South Africa invested in 75 projects on the continent - more than any other country.

\section{BRICS Companies on African Markets}

More than 2,500 Chinese companies are doing business in Africa in finance, energy, manufacturing and telecommunications. Among them are big corporations such as the China Harbour Engineering Corporation (involved in building bridges and ports), Road and Bridge Construction Company Limited (109th among the top 225 corporations in the world), which has engaged in approximately 500 projects in Africa; and the China Railway Construction Corporation, which won some tenders in Africa in 2012 [Deych, 2014, pp. 166-67]. By the end of 2013 the total volume of projects contracted by Chinese companies in Africa included the construction of more than 2,200 kilometres of railways and 3,500 kilometres of roads.

Africa's natural resources receive special attention from Chinese and Indian companies. China's leading oil companies are very active in Angola, Nigeria and Sudan. Among them are the China Petroleum and Chemical Corporation (Sinopec), which is in the top 10 Asian oil corporations, the China National Petroleum Corporation (responsible for $66 \%$ of China's oil and gas production and $42 \%$ of processing), and the China National Offshore Oil Corporation [Deych, 2014, p. 185]. Despite the frequent accusation that Chinese companies use workers from China instead of hiring locally, according to Chinese sources more than $85 \%$ of the employees and staff engaged in Africa by Chinese corporations are African people [APC Communiqué, 2012].

The footprints of Indian private sector and public sector enterprises can be seen in Africa. Major private sector enterprises include Tata, Mahindra and Mahindra, Ranbaxy Laboratories, Fortis, Vedanta, Kirloskar Brothers Limited, Bharti Airtel Communications and NIIT Technologies. In March 2014, the state-owned Oil and Natural Gas Corporation Limited (ONGC Videsh) and Angola's Sonangol signed an agreement to development oil found in the sea shelf. Indian companies participate in developing coal and gas deposits in Mozambique. Public sector enterprises such as Indian Telephone Industries, Rail India Technical and Economic Services (RITES) and Konkan Railways are also very active in Africa [Verma, 2012]. India willingly uses local staff in its African projects, so its policy is less criticized on the continent. 
Large Brazil companies are also active in Africa, particularly in the oil and gas and mining sectors. There are more than 100 Brazil firms in Angola, where 30,000 Brazilians work [Kiala and Ngwenya, 2011]. Vale do Rio Doce (Vale) operates in seven African countries, including a coal project in Mozambique responsible for creating 4,500 jobs. Vale plans to invest in Africa $\$ 12$ billion over five years, with $\$ 8.2$ billion going to Mozambique [Kinch, 2012]. The oil giant Petrobras, active in 28 countries, invested \$3 billion in Africa between 2009 and 2013. The construction company Odebrecht engages in biofuel production in Angola, Libya, Liberia, Mozambique and Ghana. Its first plant, producing ethanol, was built in Sudan.

Eighteen major Russian companies have 40 projects in Africa, mainly in mining. Rusal, one of the world leading aluminum producers, has operations in Namibia, Guinea, South Africa, Angola and Nigeria. Lukoil has invested in oil exploration in Cote d'Ivoire, Sierra-Leone and Ghana [AfDB, Organisation for Economic Co-operation and Development (OECD), United Nations Development Programme (UNDP) and UNECA, 2011] . The important projects are the development of manganese and vanadium in South Africa by Renova and Evraz; iron in Liberia, Congo and Gabon by Severstal; and diamonds in Angola by ALROSA. Gazprom is developing oil fields in Algeria, Nigeria, Namibia and Equatorial Guinea [Korendyasov, 2013, pp. 100-01].

South African companies play important role in the energy, mining and food sectors in African economies. Sasol, a global player in energy and chemical industries, is active in Mozambique, Botswana, Gabon and Nigeria. Anglo Gold Ashanti, the first South African gold extractor, operates in Ghana, Mali, Namibia and Tanzania [UNECA, 2013, p. 16]. The agribusiness firm Tiger Brands has made acquisitions in Nigeria, buying the biscuit manufacturer Deli Foods Nigeria in 2011 and a 63.5\% stake in Dangote Flour Mills in 2012 [Mthembu-Salter, 2013].

\section{Focus on African Infrastructure}

Poor infrastructure is a major impediment to faster economic development in Africa. The continent loses two percentage points of GDP growth annually as a result of its infrastructure deficit. According to the World Bank, in 2011 16\% roads were paved in sub-Saharan Africa, compared to $26 \%$ in Latin America, $65 \%$ in East Asia and $79 \%$ in member countries of the Organisation for Economic Co-operation and Development (OECD). [Marlier, 2014]. Only one in three Africans had access to electricity, compared to nine in ten people elsewhere in the developing world [Ibid.].To close this gap, Africa must invest about $\$ 93$ billion a year in infrastructure within a decade, but in 2011 spent only $\$ 45$ billion [KPMG, 2011].

The BRICS countries have paid special attention to this problem. They have been more involved in African infrastructure than western countries. The eThekwini Declaration, issued at the fifth BRICS summit, shows that African infrastructure is among the priorities of BRICS foreign policy. The BRICS countries declared: "We will seek to stimulate infrastructure investment on the basis of mutual benefit to support industrial development, job-creation, skills development, food and nutrition security and poverty eradication and sustainable development in Africa” [BRICS, 2013].

In 2012 China became the number-one outside investor in African infrastructure, with $\$ 13$ billion invested. The next largest investor was the World Bank at about $\$ 4$ billion [Frimpong, 2014]. China participated in more than 500 infrastructure projects. It followed the principle of raw materials in exchange for infrastructure; its agreements include investing not only in resource extraction but also in railways and roads, dams, power stations and buildings. In 2012 Xu Jintao said about 100 schools, 30 hospitals, 30 anti-malaria clinics and 20 centres for dem- 
onstrating agricultural technologies had been built with Chinese aid in Africa [Ighobor, 2013]. The new AU headquarters in Addis Ababa, Ethiopia, is called "China's gift to Africa" - Beijing has built it free of charge.

China has been awarded a contract for restoring the Benguela railway connecting the copper belt of Zambia and DRC with the Angolan port of Lobito, with a contract to construct the rail system from the interior Nigeria to the coast. Chinese companies are building railways in South Africa and Mozambique and the highway in Kigali, the capital of Rwanda. The visits of Nigeria's Goodluck Jonathan and Kenya's Uhuru Kenyatta to China in 2013 resulted in loans for infrastructure development: Kenya received \$3.75 billion for the construction of MombasaNairobi-Malabo railway to connect Kenya, Uganda, Rwanda and DRC, a key project in Kenya's "Vision-2030" national development strategy [Ndonga, 2013]. In 2014, Uganda invited six Chinese companies to compete for up to $\$ 8$ billion in contracts to expand its railway network and help improve trade routes with four bordering countries [Ojambo, 2014].

The TAZARA railway, connecting the copper belt of Zambia to the Indian Ocean through the territory of Tanzania, built by China in the 1960s, is still called a "project of the century." Beijing is constantly investing in the repair of this road and intends to combine it and Benguela railway in Angola. This will create an east-west corridor across the continent to accelerate the flow of goods and help African integration.

Brazil's activity in African infrastructure is also growing. Odebrecht has completed projects in Congo, Botswana, South Africa, Gabon and Djibuti. Africa needs not only roads and bridges, but also human employment, so the company employs local workers for the job. In Liberia, where it is building a railway and where the unemployment rate is $80 \%$, people come for hundreds of kilometres to the site in Monrovia in search of work [Lewis, 2011].

Through its President Infrastructure Initiative, South Africa is engaged in nine big African projects and fully financing two of them. Among them are the terminals in Dar Es-Salam, Tanzania, the port in South Africa's Durban and a railway in Zimbabwe. According to the development strategy presented by South African government in 2012, Transnet is investing \$39.1 billion for seven years to develop South Africa's port and railway infrastructure. The strategy foresees the growth of transportation volumes from 200 million to 350 million tonnes per year and the creation of 588,000 jobs. South Africa's Spoornet, with shares of $80 \%$ in African railways, is reconstructing the rail line linking Ethiopia and Eritrea. The South African government has allocated $\$ 1.5$ billion for constructing the railway between South Africa and Swaziland, which will cost $\$ 2$ billion and will take three years from 2013 to 2016 [Phatkathi, 2012].

\section{The Banking Sector as a Coordinator of Financial and Economic Cooperation}

The banking sector plays a significant role in financial and economic cooperation between the BRICS and Africa. First, it involves Chinese financial institutions, which participate actively in aid and investment in African countries. The state-owned China Development Bank (CDB) oversees government equity support for Chinese corporations in commercial activities in Africa. The CDB has overtaken the World Bank and the Asian Development Bank as the largest financial institution providing overseas loans. The CDB launched the China-Africa Development Fund in June 2007 with a $\$ 1$ billion fund to encourage and support Chinese business operating in Africa. In 2013 Wang Yong, CADF executive vice president, said that in the past six years fund had committed $\$ 2.4$ billion in 64 projects in more than 30 African countries [Wakaba, 2014]. The China Eximbank has become the world's largest export credit agency with significant and expanding operations in Africa. Ethiopia's Mulatu Teshome said that "these institutions are playing a very significant role in Africa's economic development” [Moody and Chao, 2014]. 
The India Exim Bank also manages loans and credits to African countries. Asian banks are working closely with the African development banks, including the African Export-Import Bank (Afreximbank), the ECOWAS Bank for Investment and Development, and the East African Development Bank.

In 2009 the Brazilian Development Bank (BNDES) started a line of credit worth $\$ 265$ million and another one worth $\$ 360$ million in 2010 for companies willing to conduct business in Africa [IPEA and World Bank, 2012, p. 6]. BNDES disbursed roughly \$2.9 billion to underwrite projects in Africa between 2007 and 2014 [Muggah, 2015]. In 2013 it has opened an office in Johannesburg.

Russia's Vneshtorgbank opened the first bank in Angola to have predominantly foreign ownership, and then moved into Namibia and Cote d'Ivoire. Renaissance Capital owns 25\% of the shares in Ecobank, one of the largest banks in Nigeria [UNCTAD, 2013a].

South Africa is also engaged in BRICS banking with Africa. The continent's five biggest banks are South African, and all of them finance African projects. Standard Bank has an extensive continent-wide footprint and plays an important role in financial assistance to African countries. South Africa also invests in Africa through the Industrial Development Corporation and the Development Bank of South Africa.

The recently created New Development Bank (NDB), with an initial capital of $\$ 50$ billion, which later will grow to $\$ 100$ billion, must contribute to expanding investment cooperation for implementing infrastructure projects in Africa. The aim of this bank is to mobilize resources for infrastructure projects and sustainable development in BRICS countries and other emerging economies and developing countries, including in Africa. The bank will have a regional centre in South Africa. The NDB and its reserve currency pool of $\$ 100$ billion are alternatives to the World Bank and the IMF, where the North countries play the decisive role. In this sense the BRICS is a system for South-South cooperation. The new bank demonstrates the changes that have been taking place in the world over the last decade. As Mark Adomanis [2014] wrote, "Ten years ago the creation of such bank would have been greeted with open derision and laughter in Washington, London, Paris, and other western capitals. They're certainly not laughing anymore."

\section{Soft Power as an Important Tool for the BRICS}

The BRICS actively pursues its foreign policy goals through the use of soft power. Human resources receive special attention. The long-term goal is to form African elites, oriented on South-South cooperation. BRICS activity embraces such spheres as health care and education. The first meeting of BRIC health ministers in 2011 issued "The Beijing Declaration," which emphasized cooperation with international healthcare organizations and among BRICS countries for transferring effective technologies and providing developing countries with highquality medicines [Sidibé, 2011]. The BRICS governments and private enterprises participate in the African healthcare sector, including building hospitals and anti-malaria clinics and training medicine specialists.

At the FOCAC ministerial conference in 2012, Hu Jintao declared that China would shift development assistance for Africa from "hard" infrastructure assistance to "soft" assistance, and would stress education, people-to-people exchange and joint research [Zhang, 2013].

The Chinese telecommunications giant Huawei has signed contracts for $\$ 400$ million to provide mobile links for Kenya, Zimbabwe and Nigeria. ZTE invested in the modernization of television and telephone networks in several African countries. Companies such as Huawei and ZTE force out western telecommunications companies in some African countries. To assist the 
development of human resources in Africa, China proposed the African Talents Programme to provide training for 30,000 professionals in various fields [Chinese and African Foreign Ministers, 2013]. In 2012 scholarships for education in Chinese universities were granted to 20,000 Africans. Beijing created 38 Confucius Institutes in Africa, where students learn the Chinese language, history and culture [Li, 2014]. Programmes for scientific exchanges and common research projects are also being developed.

India is engaged in creating a single African system of fibre-optic and electronic communications (the Pan-Africa Network) to provide Indian educational and medical support to participating African countries, remotely via satellite technology. Telecommunications Consultants India Limited is implementing the project on a turnkey basis through a $\$ 125$ million grant. The project will provide tele-consultations for selected hospitals in Africa with 12 super specialty hospitals in India. Indian medical institutions will also offer separate daily consultations to hospitals in 54 African countries. As of January 2013, more than $\$ 30$ million of the $\$ 125$ million has been spent. By 2013, 12 super specialty hospitals were connected to 48 African hospitals where 460 tele-consultations and 2,500 continuing medical education sessions had been conducted. Simultaneously, 47 training centres were connected to five Indian universities, and nearly 10,000 students had signed up for various courses and more than 3,500 tele-education sessions had been conducted.

The Indian Technical and Economic Training Programme is active in Africa. By 2012, $\$ 2.8$ billion had been spent on the programme since its launch in 1964 , with $\$ 1$ billion used to support training and technical assistance to African countries. The Indian government increased the number of spots reserved for Africa in training programmes from 531 in 2007/08 to 998 in 2010/11 [Mullen, 2014, p. 5].

Over the years, such programmes have been able to create a network of people in Africa associated with India, including politicians, civil and business communities. The number of Indian educational programmes in Africa is growing. Training is conducted in English and the price is lower than for traditional donor training. India provides support to African research centres, including the Institut de Tunis in Tunisia, the Institute of Mathematics and Physical Sciences in Benin, and the School of Science and Technology of Masuku in Gabon. India plans to create more than a hundred scientific, innovation centres and institutions in Africa for human resources development [Usov, 2013, p. 243].

In 2011 Brazil signed 53 bilateral agreements on health care with 22 African countries. With its rich experience in tropical medicine, it has invested in specialized health centres on the continent. With the assistance of the Oswaldo Cruz Foundation, its leading medical research institute, Brazil invested about $\$ 23$ million to create a factory to produce generic drugs for treating HIV/AIDS in Mozambique, where $10 \%$ of the population is infected by the virus. The factory began operating in 2012.

Brazil has provided scholarships for African students to complete their graduate and undergraduate education in Brazilian public institutions. It helped Cape Verde to create its first public higher education institution in 2006 and in 2010 inaugurated the Afro-Brazilian University of Integration, opened to students and professors from African countries. Students from Nigeria, Tanzania and other African countries study innovation in agricultural technologies through EMBRAPA [Juma, 2013].

In 2010 the Russian company Prognoz began to create a unified continental network in Africa for the exchange and dissemination of statistical data. By the end of 2011, it completed the work on the statistics portal of the African Development Bank and created 10 applications for statistical agencies in African countries. It released a software package for Mozambique in 2011 and for Rwanda in 2012. It has signed a contract to create a portal with data for the socio- 
economic development of the 19 member states of the Common Market for Eastern and Southern Africa (COMESA). CEO Dmitriy Andrianov stated that "there is a real prospect to ensure the most countries of the continent by such developments" [Afrocom, 2012].

Russia's voluntary contribution to the Global Fund is $\$ 235$ million. It has contributed \$20 million to the World Bank programme against malaria in Africa and \$18 million to support the World Health Organization action against polio [Korendyasov, 2013, pp. 107-08]. In 2014 Russia paid \$30 million to the fund to fight the Ebola epidemic in West Africa. Russia is also involved in educating and training professionals. From 2008 to 2012 it allocated $\$ 43$ million to the World Bank for the implementation of an international programme to improve the quality of basic education, which was initiated by Russia. There are 4,500 Africans studying in Russia's higher education system, and 8,000 Africans have received their education at Russian universities [UNECA, 2013, pp. 16-18]. In 2013 the Russian government granted 750 scholarships to African students [Vasilyev and Korendyasov, 2014].

The main South African company involved in telecommunications is MTN, which is a mobile telecommunication group with licences in 21 countries across Africa and the Middle East. The insurance firm Sanlam and the media firm Naspers are also active in Africa. South Africa is engaged in challenge of health care in African countries. In 2003 Aspen Pharmacare launched the first antiretroviral drug developed and manufactured in Africa. Now Aspen is one of the leading global players in generic antiretroviral drugs [Maritz, 2014].

\section{The BRICS and Africa's Security}

What brings the BRICS members together is a common interest in creating a just and democratic world order based on a collective approach to resolving international problems and the rule of international law. The BRICS rejects the attempts of one country or a limited number of countries to impose their will on the rest of the world. The five countries' cooperation in the UN proves that eloquently. More generally, with regard to the Middle East and Africa, the BRICS has declared that the use of force should be avoided. The Fortaleza Declaration issued at the sixth BRICS summit in 2014 states: "We condemn unilateral military interventions and economic sanctions in violation of international law and universally recognized norms of international relations. Bearing this in mind, we emphasize the unique importance of the indivisible nature of security, and that no State should strengthen its security at the expense of the security of others" [BRICS, 2014]. The leaders "expressed the deep concern at the deterioration of the security and the humanitarian situation in West Africa" and commended the efforts of the international community "in addressing instability in Africa through engagement with, and coordination by, the AU and its Peace and Security Council." They added: "We call upon all parties in these conflicts to cease hostilities, exercise restraint and engage in dialogue to ensure return to peace and stability."

All BRICS countries are active in UN peacekeeping on the African continent. In April 2015, according to the UN, 8,112 peacekeepers from India, 1,678 from Brazil, 2,135 from South Africa, 2,899 from China and 68 from Russia participated in peacekeeping operations [UN Peacekeeping, 2015a].

China plays a significant role in peacekeeping operations in Africa. At the end of 2012, there were Chinese experts and police personnel assigned to six of the seven UN peacekeeping operations in Africa. China is the highest contributor of peacekeepers among the members of the UN Security Council. The South Sudan crisis pointed China's emergent peacekeeping role. The team of 331 officers and soldiers made a significant contribution to the conflict-ridden country in 2011. But the UN mission to Mali in 2013 was the first where the Chinese had com- 
bat mandate [CCTV Africa, 2014]. When a conflict broke out between government and rebellious groups in South Sudan in May 2014 Beijing sent 850 soldiers [Sapa-AFP, 2014].

India has displayed the capacity to make large contributions to UN peacekeeping activities in Africa. Its contribution is the third largest in the world and the top BRICS member, with more than 9,300 peacekeepers deployed in various missions in Africa in 2010 [van Rooyen, 2010]. India and China are engaged in the struggle against piracy on the coast of Somalia. To counter piracy, a working group has been set up to look into the economics of piracy, and three ships of the Indian Navy patrol the Gulf, the Arabian Sea and the area near the Seychelles at any given time [Verma, 2012].

Brazil also participates in UN peacekeeping missions in Africa. As of April 2015, it had eight observers in the UN mission in the Western Sahara, three peacekeepers in the UN Interim Security Force for Abyei, four in the UN Mission in Liberia, 10 in the UN Mission in South Sudan and six in the UN Operation in Côte d'Ivoire [UN Peacekeeping, 2015b].

Russia is not among the leading actors in UN peacekeeping, although its peacekeepers take part in all the UN missions in Africa and its role is growing. Russia also takes part in African peacekeeping training. The number of African annually trained in Russia has increased to 400.

South Africa ranks third among the BRICS countries in the number of peacekeepers it provides to UN missions. It also uses its diplomacy and political influence by sponsoring peace talks and participating in the settlement of conflict situations on the continent.

\section{The BRICS in Africa: Problems and Prospects}

Since 2014, the forecasts for the BRICS and its policies in Africa have grown pessimistic. In their analytical calculations the Goldman Sachs economists predicted if the rate of development of the BRICS countries does not decline, collectively they could be larger than the six leading industrial countries combined by 2039 [Walker, 2014]. However, growth in all five countries has begun to slow, especially in Brazil and Russia. There is now a downturn in the Chinese economy, which has enjoyed extremely high rates of growth for the last three decades. In 2014 its economy grew $7.45 \%$, the weakest growth in 24 years. The IMF considers "geopolitical risks," and, more precisely, Ukraine and the Middle East, as a major threat to global economic recovery [Ibid.]. Its forecasts have drawn attention to problems holding back the forward movement of the BRICS such as the role of commodity exports in the Russian and Brazilian economies in weakening their competitiveness and attractiveness for business.

However, many economists believe that the BRICS can change the situation, noting in particular that China is seeking a more sustainable model of economic development. India seems to be causing less anxiety in financial markets and international economic institutions at the moment. Many investors have welcomed the new government of Narendra Modi, which took office in May 2014. Jim O'Neill, who coined the acronym BRICS when he was at Goldman Sachs, says: "I am more optimistic than I have been for some time about India" [Walker, 2014].

Each BRICS country has its advantages in Africa. China is the largest partner of African countries in trade, investment and development aid. There are significant financial possibilities for China to participate in many projects in Africa, particularly regarding infrastructure. Unlike China-Africa cooperation, where state corporations play the leading role, India-Africa cooperation is mainly at the level of large and medium-size private business. India provides less financial aid to Africa than China, but is the first among BRICS countries in technologies and services transfer. 
Brazil gives Africa less funding than China and India and instead focuses on technical aid and on the transfer of technologies, services and expertise, particularly in the agricultural sector. Since 2012 Brazil has been carrying out a national programme of farming, and passes on its experience to African countries. The advantages of Brazil's agricultural model include vertical integration, state support and a high level of mechanization. Brazil also has the advantage of traditional ties with Africa, with more people of African descent than anywhere outside the continent. Brazil focuses is Lusophone Africa, and its relations with these countries are based on a common language. Brazil tries to avoid the mistakes that other BRICS countries have made in Africa. For example, its companies use local staff actively, contributing to solving the problem of unemployment: about $90 \%$ of Odebrecht employees in Africa are Africans [Economist, 2012].

Russia's advantage is its rich experience of cooperation with African countries, accumulated during the Soviet period. Many former Soviet students occupy leadership positions in Africa and fondly remember their years of study in the USSR. Russia can use these ties with Africa in order to improve bilateral relations.

Having become the fifth BRICS member in 2010, South Africa considers its membership an opportunity to raise the international perception of its role as a regional leader of Africa. Its membership in the BRICS has received much criticism. Even O'Neill was dissatisfied with the addition, noting that the South African economy is not comparable with the economies of other members of the group. Its abilities are not generally recognized. In March 2013 Germany's Bertelsmann Fund stated that South Africa was not a model of sustainable development, because it had not made progress in such important areas as education and social development and it could not put an end to unemployment. It also said that other African economies grow more successfully. However, according to Bheki Lang, South Africa's ambassador to China, South Africa's participation in the BRICS is justified because it plays the role of a financial "gateway" to Africa south of the Sahara and has a more powerful economic potential than other African countries [Tang, 2013]. Although South Africa may be inferior to the other BRICS members by economic parameters, its advantages are its rich resources, a strong financial and banking sectors, and experience in initiating and developing modern economic strategies (NEPAD) and regional economic integration (SADC). South Africa is also the sole state on the continent to have global-level high technologies.

Although the BRICS countries declare their willingness to cooperate, they still act as rivals in Africa. India competes with China for access to African markets. Major Chinese investment in African infrastructure and also recently in technology has forced India to seek opportunities to outstrip China, primarily in the areas of new technologies and human capital development. Brazil and India are eager to become permanent members of the UNSC, which also makes them competitors. China, India and Brazil compete with regard to African agriculture, where each is very active. Brazil is trying to counter China and India in Lusophone Africa, which it regards as its sphere of influence.

Nevertheless, there is a broad range of global problems where the interests of the BRICS and Africa coincide, and there are many fields where they can cooperate fruitfully. In spite of the competition for markets and resources in Africa, there are joint initiatives such as the India-Brazil-South Africa Trust Fund (IBSA Trust Fund) managed by the UNDP's Special Unit for South-South Cooperation. The fund has provided funding from the three countries for projects in several LDCs in Africa, including Burundi, Cape Verde, Sierra Leone and Guinea Bissau. Things may move ahead: in 2015 in Brazil the BRICS ministers of science and technology signed a memorandum of understanding on science, technology and innovation that will provide a strategic framework for cooperation. According to a spokesperson at the Science 
and Technology Division of Brazil's Ministry of Foreign Affairs, the BRICS countries have already identified five priority fields of action regarding scientific cooperation [Ortiz, 2014]. The BRICS Business Council currently works on a number of promising multi-party projects, including some to improve the investment climate. The BRICS offers a new model of infrastructure co-funding, which can help BRICS countries work together in Africa and promote African integration. Russia has prepared a draft strategy of multi-party economic cooperation among the BRICS countries. The key provisions of the strategy are specified in another document prepared by the Russian side - a roadmap of investment cooperation, which incorporates 37 projects in various areas from high technologies to humanitarian matters [Mcilhone, 2014]. According to the "Concept of Russian Federation Participation in BRICS," Russia wants to see the BRICS as a model of global relations and hopes that BRICS countries will work in Africa jointly [Paniyev, 2013].

The BRICS plays a bridging role between developed and developing countries. At the World Trade Organization it calls for reduced agricultural subsidies by the United States and the European Union, in order to increase the competitiveness of African agricultural products. It provides support for African countries in the negotiations on climate change. The BRICS stands for just democratic international order. The presence of the BRICS in Africa balances the traditional West supremacy on the continent. The BRICS has not only changed traditional trade and investment relations for African states, but has also created big opportunities for African economies: Africa's growth is greatly influenced by its relationship with the BRICS. Africans appreciate the advantages brought by the aid and cooperation of BRICS members. For many years they adopted a western aid and followed western models of development, but never managed to put an end to underdevelopment. In their view, countries such as China, India, Brazil and Russia, and now South Africa, can bring something new within the scope of cooperation with African countries, can help them to solve some of the challenges of development and can help Africa achieve the Millenium Development Goals.

\section{References}

Adomanis M. (2014) BRICS bank, Ukraine likely to dominate 2014 BRICS summit. BRICS Post, 9 July. Available at: http://thebricspost.com/brics-bank-ukraine-likely-to-dominate-2014-brics-summit (accessed 25 May 2015).

African Development Bank (2013) "Africa and the BRICS: a win-win partnership?" Tunis, 10 July. Available at: http://www.afdb.org/en/blogs/afdb-championing-inclusive-growth-across-africa/post/africa-and-the-bricsa-win-win-partnership-12098/ (accessed 25 May 2015).

African Development Bank, Organisation for Economic Co-operation and Development, United Nations Development Programme and United Nations Economic Commission for Africa (2011) "African economic outlook 2011: Africa and its emerging partners.” Tunis. Available at: http://www.afdb.org/fileadmin/uploads/ afdb/Documents/Generic-Documents/Media_Embargoed_Content/EN-AEO_2011_embargo\%206\%20 Juin.pdf (accessed 25 May 2015).

Afrocom (2012) Rossiyskiye kompaniji na IT- rynke Afriki [Russian cmopanies in the African IT market]. 23 April. Available at: http://www.afrocom.ru/news/analytics/21 (accessed 25 May 2015).

APC Communiqué (2012) China's Africa envoy discusses China-Africa relations. Fall. African Presidential Centre, Boston University. Available at: http://www.bu.edu/apc/files/2012/09/Fall-2012-CommuniqueAmb-Zhong-Jianhua.pdf (accessed 25 May 2015).

Blanchard B. (2014) China to extend over $\$ 12$ bln in aid to Africa. Reuters, 9 May. Available at: http://www. reuters.com/article/2014/05/09/us-china-africa-idUSBREA4802320140509 (accessed 25 May 2015).

Borzova A. (2014) Brazil's cooperation with Africa (agricultural aspect). In: T. Deych et al., eds., Africa's growing role in world politics. Moscow: Institute for African Studies, Russian Academy of Sciences, pp. $282-88$. 
Available at: http://www.histant.ru/sites/default/files/inafran/2014/Africas\%20growing\%20role.pdf (accessed 25 May 2015).

BRICS (2013) "BRICS and Africa: partnership for development, integration and industralisation." eThekwini Declaration, Durban, 27 March. Available at: http://www.brics.utoronto.ca/docs/130327-statement.html (accessed 25 May 2015).

BRICS (2014) "The 6th BRICS summit: Fortaleza declaration.” Fortaleza, Brazil, 15 July. Available at: http:// www.brics.utoronto.ca/docs/140715-leaders.html (accessed 25 May 2015).

CCTV Africa (2014) "China's peacekeeping mission in Africa." 13 March. Available at: http://cctv-africa. com/2014/03/13/chinas-peacekeeping-mission-in-africa/ (accessed 25 May 2015).

China Analyst (2014) "Regional focus: China-Africa.” Beijing Axis, April. Available at: http://www.thebeijingaxis. com/tca/editions/the-china-analyst-apr-2014/236-regional-focus-china-africa (accessed 25 May 2015).

Chinese and African Foreign Ministers (2013) "Joint communiqué of the third round of political consultations between Chinese and African foreign ministers." New York, 23 September. Available at: http://www.fmprc.gov. cn/mfa_eng/wjdt_665385/2649_665393/t1080313.shtml (accessed 25 May 2015).

Confederation of Indian Industry and World Trade Organization (2013) "India-Africa: South-South trade and investment for develoment.” Available at: https://www.wto.org/english/tratop_e/devel_e/a4t_e/global_ review13prog_e/india_africa_report.pdf (accessed 25 May 2015).

Deych T. (2014) Kitay "zavoevyvaet" Afriku [China "wins" Africa]. Moscow: Institute for African Studies, Russian Academy of Sciences.

Economist (2012) Brazil in Africa: A new Atlantic alliance. 10 November. Available at: http://www.economist. com/news/21566019-brazilian-companies-are-heading-africa-laden-capital-and-expertise-new-atlanticalliance (accessed 25 May 2015).

Ernst and Young (2011) “2011 Africa attractiveness survey.” Available at: http://www.ey.com/ZA/en/Issues/ Business-environment/2011-Africa-attractiveness-survey (accessed 25 May 2015).

Freemantle S. and J. Stevens (2013) BRICS trade is flourishing, and Africa remains a pivot. 12 February. Johannesburg: Standard Bank. Available at: https://m.research.standardbank.com/API/Asset/ PrintPDF?docId=1671-5E15D65CF1904D22850B65E04864FC94-1 (accessed 25 May 2015).

Frimpong P. (2014) "BRICS and Africa." Vibe Ghana, 30 July. Available at: http://vibeghana.com/2014/07/30/ brics-and-africa/ (accessed 25 May 2015).

George E. (2014) Brazil's trade with Africa. 9 April. Saõ Paulo: Ecobank. Available at: http://www.ecobank. com/upload/20140617035947280312cgkaDWNv9b.pdf (accessed 25 May 2015).

Green A. R. (2012) Russia-Africa trade: set for a WTO boost? This Is Africa, 12 November. Available at: http:// www.thisisafricaonline.com/News/Russia-Africa-trade-Set-for-a-WTO-boost?ct=true (accessed 25 May 2015).

Grimm S. (2013) South Africa: BRICS member and development partner in Africa. China Monitor, pp. 38-44. Centre for Chinese Studies, University of Stellenbosch. Available at: http://www.brics5.co.za/assets/AAA3.pdf (accessed 25 May 2015).

Hu J. (2012) "Chinese president's speech at opening ceremony of Fifth Ministerial Conference of Forum on China-Africa Cooperation.” 19 July. Available at: http://news.xinhuanet.com/english/china/2012-07/19/ c_131725637.htm (accessed 25 May 2015).

Ighobor K. (2013) China in the heart of Africa. Africa Renewal, 20 August. Available at: http://www. buzinessafrica.com/index.php?option $=$ com_content\&view $=$ article $\&$ id $=910 \% 3$ Achina-in-the-heart-of-africa $\&$ catid $=8 \% 3$ Achina\& Itemid $=11 \&$ lang $=$ en (accessed 25 May 2015).

IPEA and World Bank (2012) Bridging the Atlantic: Brazil and sub-Saharan Africa - south-south partnering for growth. Washington DC. Available at: http://documents.worldbank.org/curated/en/2012/01/16279478/ bridging-atlantic-brazil-sub-saharan-africa-south-south-partnering-growth (accessed 25 May 2015).

Jacob J. (2015) Third India-Africa summit: preparations underway. Hindustan Times, 18 May. Available at: http://www.hindustantimes.com/india-news/sushma-swaraj-in-sa-as-india-africa-summit-begins-nextweek/article1-1348248.aspx (accessed 25 May 2015). 
Juma C. (2013) "Africa and Brazil at the dawn of new economic diplomacy." Belfer Center for Science and International Affairs, Harvard University, 26 February. Available at: http://belfercenter.ksg.harvard.edu/ publication/22793/africa_and_brazil_at_the_dawn_of_new_economic_diplomacy.html (accessed 25 May 2015).

Kiala C. and N. Ngwenya (2011) "Angola's strategic co-operation with the BRIC countries." SAIIA occasional paper no. 85, South African Institute of International Affairs, Pretoria, May. Available at: http://www.saiia.org. za/doc_download/61-angola-s-strategic-co-operation-with-the-bric-countries (accessed 25 May 2015).

Kinch D. (2012) Brazil's Africa relations now strategic: minister. MarketWatch, 3 May. Available at: http:// www.marketwatch.com/story/brazils-africa-relations-now-strategic-minister-2012-05-03 (accessed 25 May 2015).

Korendyasov E. (2013) Rossiyskiye economicheskiye interesy v Afrike [Russian economic interests in Africa]. In: T. Deych and E. Korendyasov, eds., BRICS - Africa: partnerstvo i vzaimodeystviye [BRICS-Africa: Partnership and Interaction]. Moscow: Institute for African Studies, Russian Academy of Sciences, pp. 95-100.

Korendyasov E. (2014) Russia returns to Africa. In: T. Deych et al., eds., Africa's growing role in world politics. Moscow: Institute for African Studies, Russian Academy of Sciences, pp. 239-46. Available at: http://www. histant.ru/sites/default/files/inafran/2014/Africas\%20growing\%20role.pdf (accessed 25 May 2015).

KPMG (2011) "India investing in South Africa and Africa.” Available at: http://www.kpmg.com/ZA/en/ IssuesAndInsights/ArticlesPublications/Doing-Business-with-India/Documents/India\%20investing\%20 in\%20South\%20Africa\%20and\%20Africa.pdf (accessed 25 May 2015).

Kuo L. (2013) "China promises Africa $\$ 1$ trillion in financing, but the true sum may never be known." Quarz, 19 November. Available at: http://qz.com/148520/china-promises-africa-1-trillion-in-financing-but-thetrue-sum-will-never-be-known/ (accessed 25 May 2015).

Lewis D. (2011) Special report: in Africa, can Brazil be the anti-China? Reuters, 23 February. Available at: http://www.reuters.com/article/2011/02/23/us-brazil-africa-idUSTRE71M1I420110223 (accessed 25 May 2015).

Li Y. (2014) "Work together to promote the cultural communication and mutual learning between China and Africa.” Dar es Salaam, 24 June. Available at: http://english.hanban.org/article/2014-07/11/content_544491. htm (accessed 25 May 2015).

Maritz J. (2014) "Four South African companies taking on the world." How We Made It in Africa, 29 September. Available at: http://www.howwemadeitinafrica.com/four-south-african-companies-taking-onthe-world/43690/ (accessed 25 May 2015).

Marlier S. (2014) Investing in African infrastucture. Economist Intelligence Unit, 16 September. Available at: http://www.economistinsights.com/infrastructure-cities/opinion/investing-african-infrastructure (accessed 25 May 2015).

Mcilhone M. (2014) "BRICS called to expand economic cooperation.” AfricanBrains, 16 July. Available at: http://africanbrains.net/2014/07/16/brics-called-expand-economic-cooperation/ (accessed 25 May 2015).

Moody A. and W. Chao (2014) Investment from China beneficial to Africa. China Daily, 27 January. Available at: http://usa.chinadaily.com.cn/epaper/2014-01/27/content_17261158.htm (accessed 25 May 2015).

Mthembu-Salter G. (2013) South Africa in Africa: your hinterland is there. Africa Report, 13 February. Available at: http://www.theafricareport.com/News-Analysis/south-africa-in-africa-your-hinterland-is-there.html (accessed 25 May 2015).

Muggah R. (2015) What is Brazil really doing in Africa? World Post, 4 January. Available at: http://www. huffingtonpost.com/robert-muggah/what-is-brazil-really-doi_b_6413568.html (accessed 25 May 2015).

Mullen R.D. (2014) "IDCR report: the state of Indian development cooperation.” Centre for Policy Research, Indian Development Cooperation Research Initiative, New Delhi. Available at: http://web.archive.org/ web/20150317165032/http://cprindia.org/Spring_2014_IDCR_Report_the_State_of_Indian_Development_ Cooperation.pdf (accessed 25 May 2015).

Ndonga W. (2013) Kenya-China pact a thrust for Vision 2030. CapitalFM, 20 August. Available at: http://www. capitalfm.co.ke/business/2013/08/kenya-china-pact-a-thrust-for-vision-2030/ (accessed 25 May 2015). 
Ojambo F. (2014) Uganda to invite Chinese bidders for R85-billion railway plan. Mail and Guardian, 19 June. Available at: http://mg.co.za/article/2014-06-19-uganda-to-invite-chinese-bidders-for-r85-billion-railwayplan (accessed 25 May 2015).

Ortiz F. (2014) Brics summits make little progress on science cooperation. SciDev.Net, 21 July. Available at: http:// www.scidev.net/global/cooperation/news/brics-summits-make-little-progress-on-science-cooperation.html (accessed 25 May 2015).

Paniyev Y. (2013) Russia reveals its strategy for BRICS cooperation. Russia Beyond the Headlines, 26 March. Available at: http://rbth.com/international/2013/03/26/russia_reveals_its_strategy_for_brics_ cooperation_24279.html (accessed 25 May 2015).

Patlansky L. (2014) No reason to fear Chinese investment in Africa. Business Day, 30 January. Available at: http://www.bdlive.co.za/opinion/2014/01/30/no-reason-to-fear-chinese-investment-in-africa (accessed 25 May 2015).

People's Republic of China (2013) "China-Africa economic and trade cooperation.” Information Office of the State Council, People's Republic of China, Beijing, August. Available at: http://news.xinhuanet.com/english/ china/2013-08/29/c_132673093.htm (accessed 25 May 2015).

Phatkathi M. (2012) Swaziland-South Africa: new railway line to boost economies. Inter Press Service, 17 January. Available at: http://www.ipsnews.net/2012/01/swaziland-south-africa-new-railway-line-to-boosteconomies/ (accessed 25 May 2015).

RT (2012) Russia slashes African debt and increases aid. 18 October. Available at: http://rt.com/business/ russia-africa-debt-writeoff-705/ (accessed 25 May 2015).

SA News (2013) "India 'can help Africa industrialise'.” 1 October. Available at: http://www.southafrica.info/ africa/india-011013.htm (accessed 25 May 2015).

Sandrey R., T. Fundira, N. Vink et al. (2013) BRICS: South Africa's way ahead? Stellenbosch: Trade Law Centre. Available at: http://www.tralac.org/images/docs/4654/brics-south-africas-way-ahead-complete-book.pdf (accessed 25 May 2015).

Sandrey R., E.M. Mpitsa, J. Vermaak and M. de Beer (2013) Assessing South Africa's trading relationship with China. Working paper no. D13WP03/2013, December. Trade Law Centre. Available at: http://www.tralac.org/ wp-content/blogs.dir/12/files/2014/02/D13WP032013-Sandrey-et-al.-Assessing-SAs-trading-relationshipwith-China-20131209-fin.pdf (accessed 25 May 2015).

Sapa-AFP (2014) China will send troops to South Sudan. IOL News, 30 May. Available at: http://www.iol. co.za/news/africa/china-will-send-troops-to-south-sudan-1.1696410 (accessed 25 May 2015).

Shan J. (2014) China pledges US\$81.7 million Ebola aid to Africa. Asia News Network, 25 October. Available at: http://www.asianewsnet.net/China-pledges-US\$81-7-million-Ebola-aid-to-Africa-66476.html (accessed 25 May 2015).

Shubin V. (2013) Why South Africa needs BRICS, why Brics needs South Africa. Security Index 19(3), pp. 33-44. doi: 10.1080/19934270.2013.814951.

Sidibé M. (2011) BRICS: seizing a leadership role in global health. Speech delivered at the first meeting of BRICS ministers of health, 11 July. Beijing. Available at: http://www.unaids.org/sites/default/files/media asset/20110711_SP_BRICS-health-ministers_en-1_0.pdf (accessed 25 May 2015).

Standard Bank (2012) "China-Africa ties deepen as China eyes new markets and moves up value chain." Media release, Johannesburg, 3 December. Available at: http://www.standardbank.com/Article.aspx?id=236\&src $=$ m2012_34385466 (accessed 25 May 2015).

Tang Q. (2013) “A changing world order.” Interview with Bheki Langa, South African ambassador to China. Available at: http://www.chinafrica.cn/english/The_Latest_Headlines/txt/2013-02/07/content_517419.htm (accessed 25 May 2015).

TBP and Agencies (2014) Xi, Zuma eye intensive cooperation in 2014-15. BRICS Post, 27 April. Available at: http://thebricspost.com/xi-zuma-eye-intensive-cooperation-in-2014-15 (accessed 25 May 2015).

Tjønneland E. N. (2013) Providing development aid to Africa: comparing South Africa with China, India and Brazil. SAFPI brief 25. South African Foreign Policy Initiative. Available at: http://www.safpi.org/sites/ default/files/publications/SAFPI_Policy_Brief_25.pdf (accessed 25 May 2015). 
UN Integrated Regional Information Networks (2013) Africa: untangling China's aid to Africa. 17 September. Available at: http://allafrica.com/stories/201309180914.html (accessed 25 May 2015).

United Nations Conference on Trade and Development (2013a) The rise of BRICS FDI and Africa. Global Investment Trends Monitor. Available at: http://unctad.org/en/PublicationsLibrary/webdiaeia2013d6_en.pdf (accessed 25 May 2015).

United Nations Conference on Trade and Development (2013b) Trade and development report 2013: Adjusting to the changing dynamics of the world economy. Geneva. Available at: http://unctad.org/en/PublicationsLibrary/ tdr2013_en.pdf (accessed 25 May 2015).

United Nations Economic Commission for Africa (2013) "Africa-BRICS cooperation: implications for growth, employment and structural transformation in AFRICA." United Nations Economic Commission for Africa, Addis Ababa. Available at: http://www.uneca.org/sites/default/files/publications/africa-brics_cooperation_ eng.pdf (accessed 25 May 2015).

United Nations Peacekeeping (2015a) Monthly summary of contributions (police, UN military experts on mission and troops). 30 April. Available at: http://www.un.org/en/peacekeeping/contributors/2015/apr15_1. pdf (accessed 25 May 2015).

United Nations Peacekeeping (2015b) UN missions summary detailed by country. 30 April. Available at: http:// www.un.org/en/peacekeeping/contributors/2015/apr15_3.pdf (accessed 25 May 2015).

Usov V.A. (2013) Deijatelnost BRICS po rasshireniju dostupa stran Afriki k novejshim tehnoloigijam [BRICS and the problem of IT access for African countries]. In: T. Deych and E. Korendyasov, eds., BRICS - Africa: partnerstvo $i$ vzaimodeystviye [BRICS-Africa: Partnership and Interaction]. Moscow: Institute for African Studies, Russian Academy of Sciences. pp. 236-54.

van Rooyen F. (2010) Blue helmets for Africa: India's peacekeeping in Africa. Occasional paper no. 60, May. South African Institute of International Affairs. Available at: http://www.saiia.org.za/doc_download/85-bluehelmets-for-africa-india-s-peacekeeping-in-africa (accessed 25 May 2015).

Vasilyev A.M. and E. Korendyasov (2014) Partnerstvo Rossiya-Africa: pragmaticheskiy podhod [Russia-Africa partnership: a pragmatic approach]. Analiticheskiy vestnik [Analytic News] 524(6), pp. 40-50.

Verma R. (2012). India and Africa: towards greater cooperation and growth. LSE Ideas [blog], London School of Economics and Political Science, 13 April. Available at: http://blogs.lse.ac.uk/ideas/2012/04/india-andafrica-towards-greater-cooperation-and-growth/ (accessed 25 May 2015).

Wakaba P. (2014) Symbiotic China-Africa relationship expected to grow. CCTV, 29 January. Available at: http:// english.cntv.cn/program/newshour/20140129/102875.shtml (accessed 25 May 2015).

Walker A. (2014) Whatever happened to the BRICS economies? BBC News, 27 November. Available at: http:// www.bbc.com/news/business-29960335 (accessed 25 May 2015).

World Bank (2011) Africa's Future and the World Bank support to it. March. Available at: http://siteresources. worldbank.org/INTAFRICA/Resources/AFR_Regional_Strategy_3-2-11.pdf (accessed 25 May 2015).

Zhang C. (2013) A promising partnership between BRICS and Africa: a Chinese perspective. China Monitor, pp. 30-37. Centre for Chinese Studies, University of Stellenbosch. Available at: http://www.brics5.co.za/ assets/AAA3.pdf (accessed 25 May 2015). 